\title{
Rehearsing Detachment: Refugee Theatre and Dialectical Fiction
}

Jonas Tinius ${ }^{1}$

University of Cambridge, United Kingdom

\begin{abstract}
This article responds to Nicolas Bourriaud's account of the poetic function of relational art, which for him "consists in re-forming worlds of subjectivization" (2002 [1998]: 104). I challenge and complement his account of how such reforming takes place in relational art by providing an ethnographic description of what I term 'dialectical fiction'. This notion describes actors' cultivation of detachment and reappropriation of subjectivity during theatre rehearsals by building up fictional characters. The ethnographic source for this analysis is a long-term study of the rehearsal processes for a site-specific and participatory refugee theatre and art project in an abandoned post-industrial refugee camp in the German Rubr valley. By inviting refugee actors to introduce abstract and fictitious characters into their reflections on acting and cultivation of an acting conduct, this project aspired to what its director called theatre's "impossible political utopia": a situation in which refugees are not framed as vulnerable victims "acting themselves", but as creative agents capable of playfully negotiating their political subjectivities.
\end{abstract}

Keywords: anthropology, diversity, Germany, relational art, refugees, theatre

\section{INTRODUCTION: SUBJECTIVITIES AND IMPOSSIBLE UTOPIAS}

Based on fifteen months of fieldwork in the post-industrial German Ruhr valley, this article provides an account of a theatre project in a former refugee camp in Mülheim. The artists who organised this project proposed to bring theatre to the attention of local authorities,

1 This article greatly benefitted from lively discussions before, during, and after the conference panel "Microutopias: exploring connections in anthropology, relationality and creativity" at SIEF2015 in Zagreb, Croatia. I would also like to thank the two anonymous reviewers of this article whose comments provided stimulating feedback. Author’s contact Email: j1t46@cam.ac.uk 
who were at the time dealing with acute problems of accommodating and integrating refugees into the municipal community. Some of the core questions raised by this project were: how can theatre respond to vulnerable and traumatised subjects? What kinds of subjectivities is it able to restore; which new ones can it engender?

In a conversation with the project director Adem Köstereli, he remarked that the "impossible political utopia of refugee theatre" would be a situation in which the refugee was not marked off from other subjects of the state; where refugees were not confined to a single legal identity and reduced to a merely 'tolerated' precarious and bare life (in a publication, he explicitly referred to Agamben's Homo Sacer 1998 [1995]). Adem insisted that the aspiration of the project was political and utopian; not because it shows just 'how things really are', but because it has the capacity to point to the non-existent and imagined, the eu-topia. The impossible political utopia of the project thus referred to a non-existent but desired situation in which actors would not be identified solely by recourse to the political category of the refugee. This utopian situation functioned as a central telos that affected its rehearsal process. Yet, it also described a political aim of the project that concerned its eventual audiences, since it sought to evoke a scenario in which it would be unclear if the actors were refugees, if their stories were real or fictitious.

Instead of merely documenting and re-creating the experience of refugees in the eerie post-industrial refugee camp that the project took as its performance venue, participants transformed the site itself into a place for the rehearsal of imagination where actors trained to merge their 'real' stories and imagined roles. In doing so, this project responded to and criticised a prominent political aesthetic of contemporary documentary theatre, which emphasises the authenticity of refugee actors 'playing themselves' (see Heinicke et al. 2015; Long 2015; Nikitin et al. 2014; Stegemann 2015). This critique raises a key question for anthropological studies of political art: what in our analyses of art projects with vulnerable actors can be gained from examining fiction and detachment, rather than identification and authenticity?

Rehearsals were the primary space and means to elaborate this relation of actors to their selves and thus form the central ethnographic prism through which I explore this subject. By focussing on the process rather than the impact of this theatre project, I wish to highlight subject-formation and intersubjective encounters as creative and also as laborious processes. Theatre with refugees, taught and experienced primarily through its rehearsals, became a type of method of learning, reflecting, and relating to others. For this reason I stress the working methodology in this article as the principal activity through which artists and participants repeatedly probed self-reflection and self-articulation in the context of a social, interactive realm. The work of the rehearsals can therefore be considered an artistic form of work on the self and on others in a social, interactive space with an ambiguous therapeutic telos. Working towards the "impossible political utopia of refugee theatre" through the rehearsing and training of what I term 'dialectical fiction', this project raised certain productive problems with the theme of this special issue. Can performance constitute "an effort involving the individual and collective reformation of lost subjectivity" and if so, how? (Bourriaud 2002 [1998]: 103). What is the relation between the 'real world' and an 'imagined other world' in the production of artistic encounters? How can artistic processes that focus on social encounters sustainably affect subject-formation if they remain confined to the temporary realm of artistic exhibitions or performances? What is the quality of the relations and the subjectivities that emerge in "micro-utopian" encounters? 


\section{MicRo-Utopias, ANTAGONISM AND POLITICAL SUBJECTIVITY}

\section{MicRO-UTOPIAS}

In the late 1990s, the French curator and art historian Nicolas Bourriaud elaborated a conceptual paradigm to understand new practices of political art that emerged in that decade. It appealed to anthropologists, and instigated an 'ethnographic turn' in contemporary arts practice, by producing 'participatory', 'site-specific', and 'research-based' artworks that dealt with the question of 'everyday sociality'. He termed this new form of art 'relational aesthetics'. In his programmatic book Relational Aesthetics, he defines 'relational (art)' as:

A set of artistic practices which take as their theoretical and practical point of departure the whole of human relations and their social context, rather than an independent and private space. (Bourriaud 2002 [1998]: 113)

Relational art practices have come about as a specific reaction to a fundamental societal change in the way intersubjective relations are organised in the late twentieth century. "These days", he writes, "the social bond has turned into a standardised artefact" (ibid., p. 9). In Western capitalist society today, Bourriaud argues, "human relations are no longer 'directly experienced" (ibid.). For contemporary artists, he argues, "the most burning issue" therefore is whether "it is still possible to generate relationships with the world" (ibid.). Although it could be argued that this question has been fundamental to artistic practices and representation for decades, if not centuries (see Alloa 2015), Bourriaud proposes that contemporary political performance practices focus on a specific quality of intersubjectivity: "artistic praxis appears these days to be a rich loam for social experiments" that work towards creating "hands-on utopias" (2002 [1998]: 9).

These kinds of "everyday micro-utopias" (ibid., p. 31) facilitated by relational art practices are very different from previous artistic ideas of utopias, he argues, especially from the avantgarde experiments of the 1960s and their fights for imaginations of a different society. "Art was intended to prepare and announce a future world" (ibid., p. 13). The utopias developed by political artists today, Bourriaud suggests, are no longer about grand revolutions in the world, but about a small-scale and pragmatic "learning to inhabit the world in a better way" (ibid.). Put differently, "the role of artworks is no longer to form imaginary and utopian realities, but to actually be ways of living and models of action within the existing real, whatever the scale chosen by the artist" (ibid., my emphasis). Therefore, the "substrate" of this new art "is formed by intersubjectivity" (ibid., p. 15). Intersubjectivity, in his view, is not merely a means to an end. "Being-together", "the 'encounter' between beholder and picture", or quite simply the "collective elaboration of meaning" are the actual focus and telos of relational art practices today (ibid.). The productions of his most famous exemplary relational artists consist in cooking meals for gallery-visitors (pad thai series by Rikrit Tiravanija, 1990) or other forms of critical human interaction ( $250 \mathrm{~cm}$ line tattooed on 6 paid people by Santiago Sierra, 1999). Relational art, he writes, "is a state of encounter" (ibid., p. 18). And since the contemporary relational artist "embarks upon a dialogue" through the form of their artwork - the form being the kind of encounter created through art - the aim of relational art today "resides in the invention of relations" (ibid., p. 22). I engage this paradigm here because it provides an crucial backdrop to the participatory, research-based, and site-specific arts practices employed by Adem and his team to raise ethno- 
graphically challenging questions about the relational qualities of refugee theatre. Additionally, relational art raises key anthropological questions about the relations between art, ethnography, and sociality (see GDAT 2010: 'The task of anthropology is to invent relations', Venkatesan 2012). The critical reception of relational aesthetics brought to the fore significant challenges to artistic practices aimed at social encounters, which are relevant to my subsequent analysis.

\section{ANTAGONISM AND POLITICAL SUBJECTIVITY}

As with the praxis of relational aesthetics itself, Bourriaud frequently switches between descriptive observation and questionable normative evaluation. Thus, while "TV and literature" are seen to "refer each individual person to his or her space of private consumption" and "theatre and cinema" supposedly "bring small groups together before specific unmistakable images", relational art practices are seen to be different because they "tighten the space of relations" (ibid., pp. 15-16). When he speaks of each particular artwork as a "proposal to live in a shared world" (ibid., p. 22), he therefore has particular artworks in mind, such as those produced by his protégé Rikrit Tiravanija, or Braco Dimitrijevic, Dominque Gonzalez-Foerster, and Felix Gonzalez-Torres, to name but a few. Those artists propose as artworks "moments of sociability" and "objects producing sociability" (ibid., p. 33).

Bourriaud's observations are political insofar as they concern the definition of a relational context in advance - "so as to extract production principles from it" (ibid.). Relational art practices are not just disengaged gatherings entirely devoid of critical reflection. According to Bourriaud, one of the principal propositions of relational art is that " $\mathrm{t}]$ he first question we should ask ourselves when looking at a work of art is: - Does it give me a chance to exist in front of it, or, on the contrary, does it deny me as a subject, refusing to consider the Other in its structure?" (ibid., p. 57).

Bourriaud here raises a fundamental political question about relational art, namely the extent to which it produces or inhibits the recognition of subjectivity. This is important since participatory art forms can also produce very powerful forms of semantic oppression, faux social cohesion where one should engage in critical dialogue, or even "artificial hells" (see Bishop 2012; Cook and Kothari 2001). What strikes Bourriaud in the work of relational artists, however, is "first and foremost, the democratic concern that informs it" (Bourriaud 2002: 57). He refers here to the supposedly transparent interactive possibilities enabled through relational art, "the temporary collective form that it produces" (ibid., p. 61). This effect, for him, is produced through social transparency and choice: "The aura of contemporary art is a free association" (ibid.).

The outline for a new art paradigm proposed in Relational Aesthetics has been subjected to numerous critiques from practitioners and scholars, most notably by Claire Bishop, CUNY Professor of Art History. She noted that the artistic practices described by Bourriaud insufficiently address "the divided and incomplete subject of today" (2004: 79), pointing out that when Bourriaud speaks of relational artists, he refers to educated and stable subjects. Given his explicit attention to fractured subjectivity and the commoditisation of relations, this overarching criticism initially appears redundant. She therefore suggests that when we look at political art today, we ought to consider the kinds of relations they engender. Who is the subject or actor, and what kinds of encounters are produced through art today? If for contemporary artists "it 
seems more pressing to invent possible relations with our neighbours in the present than to bet on happier tomorrows" (ibid., p. 45), then how can the relations we cultivate through theatre meaningfully continue beyond a performance into the future? If large-scale social revolutions are a relic of modernist avant-gardes, then what political aspirations are implied in the cultivation of relations in art today?

In addition, Bishop rightly points out that the "laboratory paradigm" promoted through hosting relational aesthetics by curators "including Maria Lind, Hans Ulbrich Obrist, Barbara van der Linden, Hou Hanru, and Nicolas Bourriaud" encourages temporary projects and the precarious working modalities it entails (ibid., p. 52). As she puts it, "project-based works-inprogress and artists-in-residence begin to dovetail with an 'experience economy', the marketing strategy that seeks to replace goods and services with scripted and staged personal experiences" (ibid., see also Pine and Gilmore 1999). Bourriaud addresses these criticisms levelled against relational aesthetics with regard to their confinement to galleries and museums (Bourriaud 2002: 81). Nonetheless, Bishop is correct in problematising the institutional background structures within which relational aesthetics operates and which Bourriaud acknowledges only in a conveniently haphazard way (see ibidem, p. 109). "As Hal Foster warned in the mid-1990s, 'the institution may overshadow the work that it otherwise highlights: it becomes the spectacle, it collects the cultural capital, and the director-curator becomes the star'” (Foster 1996: 198 cited in Bishop 2004: 53).

In the most recent addition to anthropological scholarship on relational aesthetics, Roger Sansi (2015) has brought to attention that such a deliberate framing of artistic interventions questions the potency of their political aspirations. He asks whether art in institutional spaces does not render impossible "the aesthetic utopia to abolish the distinction between art and life, representation and practice, inside and outside?” (ibid., p. 157, see also Bürger 1984 [1974]). Two fundamental questions arise from this critique: If large-scale social revolutions are a relic of modernist avant-gardes, how does the production of subjectivity move beyond the immediate artistic encounter into sustained reflexive sociality? And secondly, if it is still possible to create meaningful micro-utopian encounters of intersubjective collectivity but only in artistic encounters, "are they still political projects?" (Sansi 2015: 157)

\section{Dialectical fiction AND Rehearsed Relations to the SELF}

The following ethnographic account analyses the cultivation of detachment and fiction in refugee theatre. In doing so, it addresses a central shortcoming of relational aesthetics with the aim of adding a richer ethnographic understanding of reflexivity and subjectivity in participatory art. Further, this critique addresses patronage and support for a new generation of directors concerned with 'applied theatre' with marginal communities at the Theater, but it also shows how theatre that might be regarded as aimed purely at pedagogic or therapeutic ends contains a deeper concern for the cultivation of political reflexivity through art.

My principal contention with Bourriaud's characterisation of political participatory art today is that it appears besides the point to posit its capacity to be "re-forming worlds of subjectivization" (Bourriaud 2002 [1998]: 104) without asking whose subjectivities are reformed, or what worlds of subjectivisation are being construed in the process? On the one hand, this is a 
call for more detailed analyses of concrete artistic practices. On the other hand, my discontent is born of the observation that 'thick' relations are not the inevitable result of any artistic encounter. Relations can also be foreclosed, severed, or thinned out by intersubjective encounters as Marilyn Strathern variously showed to be the case in descriptions of social life (1996: 517). In order to understand the nature of the relations facilitated by artistic practices, I therefore appeal to more nuanced observations of relational formation through art. Who or what is capable of initiating relationality? Who or what is the subject of such relational sociality? This raises an important issue, rightly noted by Claire Bishop when she criticises Bourriaud for not paying sufficient attention to the kinds of relations and subjectivity addressed by relational art. She writes:

The tasks facing us today are to analyze how contemporary art addresses the viewer and to assess the quality of the audience relations it produces: the subject position that any work presupposes and the democratic notions it upholds, and how these are manifested in our experience of the work. (2004: 78)

One possible and promising perspective that may shed light on relations and subjectivity is what I introduce in the following as the dialectical process of rehearsals and the engagement with the fictitious. By observing months-long rehearsal processes, I was able to note how refugee participants in Adem's project trained to detach themselves from their personal and often traumatised or stigmatised identities by creating fragments of characters different from themselves. This process of first looking at oneself and treating oneself as a fictional 'other' in order, subsequently, to reappropriate a playfully amended version of oneself is part of a complex theatrical method I refer to as "dialectical fiction".

My usage of the term 'dialectical' is inspired by Bertolt Brecht's theatrical vocabulary. Most explicitly outlined in his "Short Organon" (2014 [1948]), Brecht drew on Marxist dialectical materialism to develop his version of epic theatre. According to this political philosophy, dialectics serves as a method for explaining social and historical change through economic contradictions and political conflicts. One of its prime sources, Hegel's dialectical philosophy of history, "codifies the spatial and temporal tensions [of interiority and exteriority] by interpreting human history as a process of 'becoming' or 'actualization' from within to without, from Spirit (Geist) into form ... unfolding an inner logic of purpose into ever-more-complex forms of organic realization (System)" (Boyer 2005: 11).

The concept of dialectics appealed to Brecht due to its insistence on unpredictability, instability, and the prospect of change (see Barnett 2015: 22). Yet it also appealed to him as a view of human subjectivity that is in constant engagement with the social and political world. In Brecht's theatrical practice, "dialectics is concerned with unpicking things that appear to be fixed, from the ways society is organised to the ways people think about themselves"(ibid., p. 24). It is crucial (albeit not necessarily intuitive) to understand that for Brecht this way of thinking about society and personal identity development through theatre "is able to make dialectics enjoyable"(“Short Organon”, 2014 [1948]: §45). Brecht does not understand enjoyment as simple entertainment; rather, "enjoyable dialectics" describes a form of playful education through theatre that does not offer ready-made answers, but stimulates reflexivity and subject-formation. In his discussion on the matter, Barnett offers the example of The Good Person of Szechwan (1943) in which the central character Shen-Te comes to the realisation that "the society in which she lives is configured in such a way that it stifles goodness" (2015:25). How can she be good if she is exploited for precisely this trait? Brecht here offers no solution, but rather thinks of enjoyable dialectics as a "new kind of entertainment" ("Short Organon”, 2014 [1948]: §23) that functions 
as a "method of thinking" about questions rather than providing answers (Barnett 2015: 26). Dialectical theatre, then, can be thought of as a form of reflexivity on actors and their roles and the audience as recipient of such dramatised processes of dialectical thinking.

Beyond acknowledging this obvious legacy of the term, I wish to propose a more contemporary reading of dialectics in theatre that takes inspiration from the notion of dédoublement, literally "doubling", which describes the relation of actors to their roles and that which they enact. As performance scholar Tracy C. Davis elaborates, dédoublement is a useful term for thinking about the specific characteristics of theatrical situations, or what she terms as "theatricality" (2003: 148). From her citation of the Oxford English Dictionary, we learn that theatricality was once defined as "[a] spectator's dédoublement resulting from a sympathetic breach (active dissociation, alienation, self-reflexivity) effecting a critical stance toward an episode in the public sphere, including but not limited to the theatre" (ibid., p. 145). In a first sense, it thus literally describes "a way of uncoupling presence and representation" (Nield 2014: 553); although it could also be argued that it is a deliberate relating of presence and representation to one another. Antonin Artaud for example wrote of the double as a form of "never completed specter" and "spectral effigy" of the actor (1958 [1938]: 134). In his essay Zur Anthropologie des Schauspielers ("On the Anthropology of the Actor"), the German philosophical anthropologist Helmuth Plessner writes: "One human embodies another. Nowhere else is this being shown to us [other than in theatre]. Poetry and fine arts embody 'indirectly' and 'in distance', in words, colours, and form, not through humans themselves" (1982 [1948]: 146).

Sophie Nield develops Tracy Davis' concept of theatricality and the double further to describe situations as theatrical when persons "appear both as themselves and as what they represent" (2014: 553). For Nield, one could think here of a judge, "who is of course a judge all the time, but nevertheless will 'appear' in his or her formal role in costume" (ibid.). Crucially, this change of perspective invites a particular approach to social situations or artistic encounters: "The point becomes to look less at what is being referred to, in terms of message, but to examine how reference is being made: what is the quality, shape, texture, hidden intent or form of the representation itself?" (ibid.). What renders a situation or space "theatrical", then, is when they are such "in which the gaze (or its possibility) is embedded" (ibid.). A situation in which this double-nature of theatre is rehearsed is a situation in which reality and fiction do not necessarily blur, but one in which they are deliberately related to each. This doublement can become a strategy of intervention or subversion comparable to the Situationist practice of détournement (see Sansi 2015: 31). Such situations are pejoratively described as "theatrical", but we can also think of self-referentiality and doublement as "generative of political potential" (Schmidt 2010: 55). Explicit self-reference and self-reflection can also be thought of as an aspect of a transformative and educative theatrical method. Wolfgang Iser has described the fictitious (or fictive, to use his term) as "an operational mode of consciousness that makes inroads into existing versions of the world" (1993 [1991]: xiv). The fictive is an act of boundary-crossing which "simultaneously disrupts and doubles the referential world" (ibid., p. xv). As such, "fictionalized doubling ... defies essentialization” (ibid.).

My intention with introducing dialectics, doublement, and fiction into an analysis of "dialectical fiction" during theatrical rehearsals is to shed light on the ways in which the act of making oneself a reference to one's own performance - beyond being an aesthetic activity - is also a political and an ethical practice. It is a political practice, because it allows for the creation of alternative visions of whichever stigmatised role is being enacted, i.e. what constitutes a refugee, 
a queer, or a disabled actor. It is an ethical practice because it invites the acting subject to engage in a process of deliberative self-cultivation.

\section{THE IMPOSSIBLE POLITICAL UTOPIA: AGAINST DOCUMENTARY REALISM}

In late 2013, I was conducting a long-term ethnographic study of a public theatre institution in the German Ruhr valley, the Theater an der Ruhr, when someone introduced me to a young theatre director, Adem Köstereli. Adem had been working at this theatre for over a decade and had been socialised into the aesthetic of the institution - an aesthetic that regards collaborative artistic self-cultivation as political engagement (see Tinius 2015a). I first met Adem when he was invited to a roundtable in the city's library, organised by the municipal Green Party. They had asked him to speak about his engagement with refugees' experiences in asylum camps in the Ruhr valley. Although Adem had a close rapport with the municipal leader of the party, who invited him to the roundtable, he was not happy with the event. He felt that he was not given sufficient time to speak about the intricacies of the project, the research he had conducted on the experiences of camp-like housing structures, about the long-term rehearsal processes, or the importance of the institutional ties with the Theater an der Rubr, which served as patron for his projects on refugees. He was disappointed that the event did not address the complexity of artistic engagement with refugees, but instead seemed primarily to serve the party's electoral campaign. He remarked that the refugees he worked with were mentioned merely as a category, positively discriminated and reified:

\footnotetext{
The people I work with are academics, musicians, therapists, writers - and actors, but of course also just people without sensational skills, just like you or me. But they are not just 'asylum seekers'. In the media, local politics, and even in documentary art, they are often only reduced to this reified category. This is realism gone wrong. (Personal communication, January 2015)
}

From that day onwards, I began accompanying Adem and his work with refugees, since I was struck by his trust and confidence in the transformative political potential of art and his scepticism towards what he called the "problem of authenticity and realism" in both local politics and contemporary art. He told me that he was in the second year of a trilogy that used theatre and site-specific art installations to challenge the homogeneous and negative image of refugees in the city's civic and political public perception, but also to question the idea that there were and had to be "real refugees" who could tell the affected and well-intentioned audiences about "their real and authentic tragedies". "As artists, we are almost committed to showing that things can also be different - the Bilder we create must show the ambivalence and complexity of human life and suffering, not lock it down in explicated scenarios", he said.

Adem invited me along to several meetings in the run-up to the project's launch. These included discussions with the CEO and artistic directors of the Theater an der Rubr on how to present the project to potential patrons and publics as well as meetings with the local city councillor in charge of cultural affairs. What was intriguing for me was that Adem and the Theater an der Rubr CEO soon decided that my perspective on the refugee trilogy should somehow feature in the project, too. They knew that I had been accompanying the Theater and its rehearsals for a long time and thus suggested that I could become involved, not as an artist but as an anthropologist. My initial concerns about becoming too involved in the project were countered by them: "No, no", they insisted, "it is precisely your presence as anthropologist that 
will make this interesting - your observation and critical distance to what we do will underline our commitment to reflexivity." Eventually, the two even decided to include a reference to me in the application, as "accompanying anthropologist". I did not object, since it was a rather apt description of what I was doing, I felt, and since I anticipated that this would yield interesting insight into the exchange and collaboration of artistic and anthropological expertise on this project (see Tinius 2015b). The project was eventually funded by the city of Mülheim and the Arts in Intercultural Dialogue scheme of the state of North Rhine-Westphalia.

On a later occasion, shortly before the project was about to begin, the Theater CEO and Adem had invited cultural correspondents from several local newspapers and regional radio stations to announce the project. Most journalists found the project's aims of creating a more nuanced and subtle artistic representation of refugees laudable. Adem had suggested a particular weekly column format to the reporters that would not portray the refugee participants of the project as tragic stories of loss, victimhood, and suffering - although these are undoubtedly significant aspects of their narrative. Instead, he wanted to base these columns on their dreams, aspirations, and creative hopes for a good life. One local journalist kindly agreed to host this column in their newspaper, suggesting that I should write these reports on the basis of my research and interviews with the project - a collaboration that led to a series of well-received alternative forms of research output that were also helpful for the project. One journalist, and it should be noted that he was an exception on the occasion, thought this idea was pointless: "The only stories people want to read about refugees are about blood, tears, and misery." This phrase stuck in Adem's head and he would bring it up on numerous occasions during my fieldwork with him, repulsed by its normative and scandalising assumptions about refugees and motivated to correct this view. On one occasion - we were in his local shisha-café where we regularly met to discuss the project, frequently with the refugees participating in his project - he remarked:

The impossible political utopia of my artistic endeavours would be if nobody recognised whether my theatre plays are with refugees or professionals. Once the audience realises that it's about the relations of actors to themselves, that it's about the work of artistic reflection, my work is completed. Art is not about facts, it brings fiction into our understanding of reality. (Personal communication, December 2013)

A young refugee actor, whom I will call Marvin, was with us that evening. He had been working with Adem for over three years and clearly agreed with what Adem said. He nodded and sipped a bit of his tea before adding:

I have now worked with you for a long time, Adem. I have been threatened with deportation a few times, but I have always been able return to what we trained and learned with you: that I can always imagine myself anew and otherwise.

Adem and Marvin were both convinced that their artistic practices were not political because they represented reality, but because they created a new reference for who one could be as a refugees. Perceiving the self, as Carlo Severi once put it, is an act of projecting an image of oneself (2003: 80). The theatrical rehearsals Marvin had accompanied - with forced interludes during which he was threatened with deportation - taught him the conduct and cognitive 'tools' for projecting new kinds of images of oneself, for imagining not just himself, but also his peers anew. In Bourriaud's words, one might say that the rehearsals provided him with means to produce new "relationships with the world with the help of signs, forms, actions and objects" (2002 [1998]: 107). 


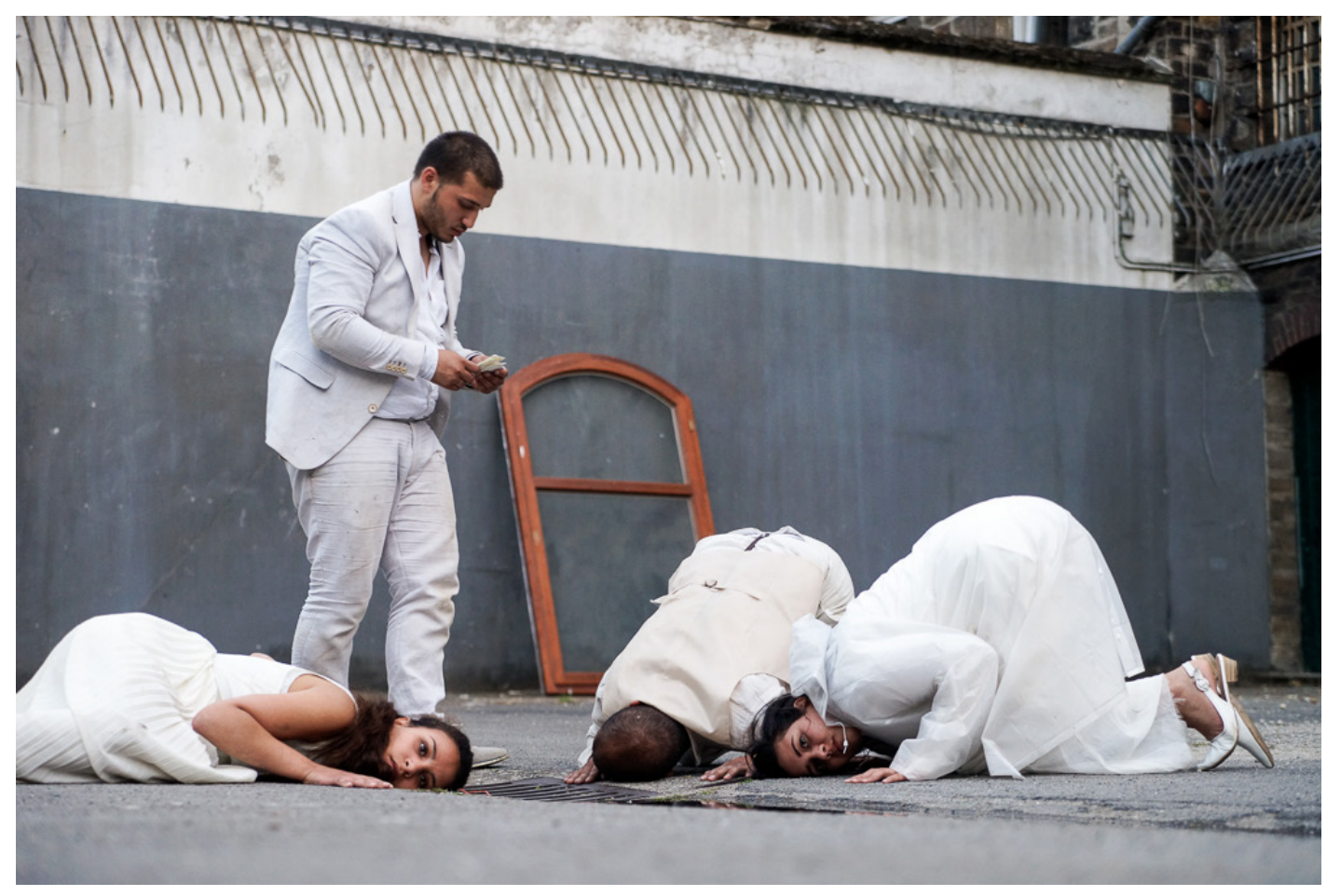

Fig. 1: Marvin (standing) during rehearsals for the trilogy's third part in 2015; (C Franziska Götzen.

\section{Dialectical Fiction I: Space And context}

In the glossary appended to Relational Aesthetics, Bourriaud defines what he calls "context" as follows:

In situ art is a form of artistic activity that encompasses the space in which it is on view. This consideration by the artist of the exhibition venue consisted, yesterday, in exploring its spatial and architectural configurations. A second possibility, prevalent in the art of the 1990s, consists in an investigation of the general context of the exhibition: its institutional structure, the socio-economic features encompassing it, and the people involved. (2002 [1998]: 109-110)

Adem's theatre and art project focussed on the subjective experiences of refugees, but it took as its starting point the context and location of the site-specific performance venue. As he wrote in the project's official proposal, "the name of our project - Ruhrorter - refers both to a location and an idea". In one sense, Ruhrorter is the name of the street on which the abandoned refugee camp was located, but literally translated from the German it also means 'pertaining to places along the Ruhr'. For Adem and the other artists involved in the project, this second meaning introduced a metaphorical dimension to the project's location; the location became a symbolic image for a range of other meanings. The site they transformed into a temporary performance and installation venue was not merely one place where refugees had been housed by the city of Mülheim (and some sections of which currently also serve as rehearsal space for the Theater an der Rubr) - it referred to the many places along the Ruhr to which refugees are distributed upon arriving in the region. This implied sense of multiple contexts, spatial dispersal, social uprootedness, and fragmentation inspired Adem to name the project after the street and building: Ruhrorter. The place thus became a real reference point anchored architecturally and spatially, but it became at the same time a sign for the experience of being a refugee in the Ruhr valley. The German term they used to describe this reality/signification play was Sinnbild, 
literally 'meaning-image'. The name as well as the site incorporated reality and imagination; it constituted a spatial doublement.

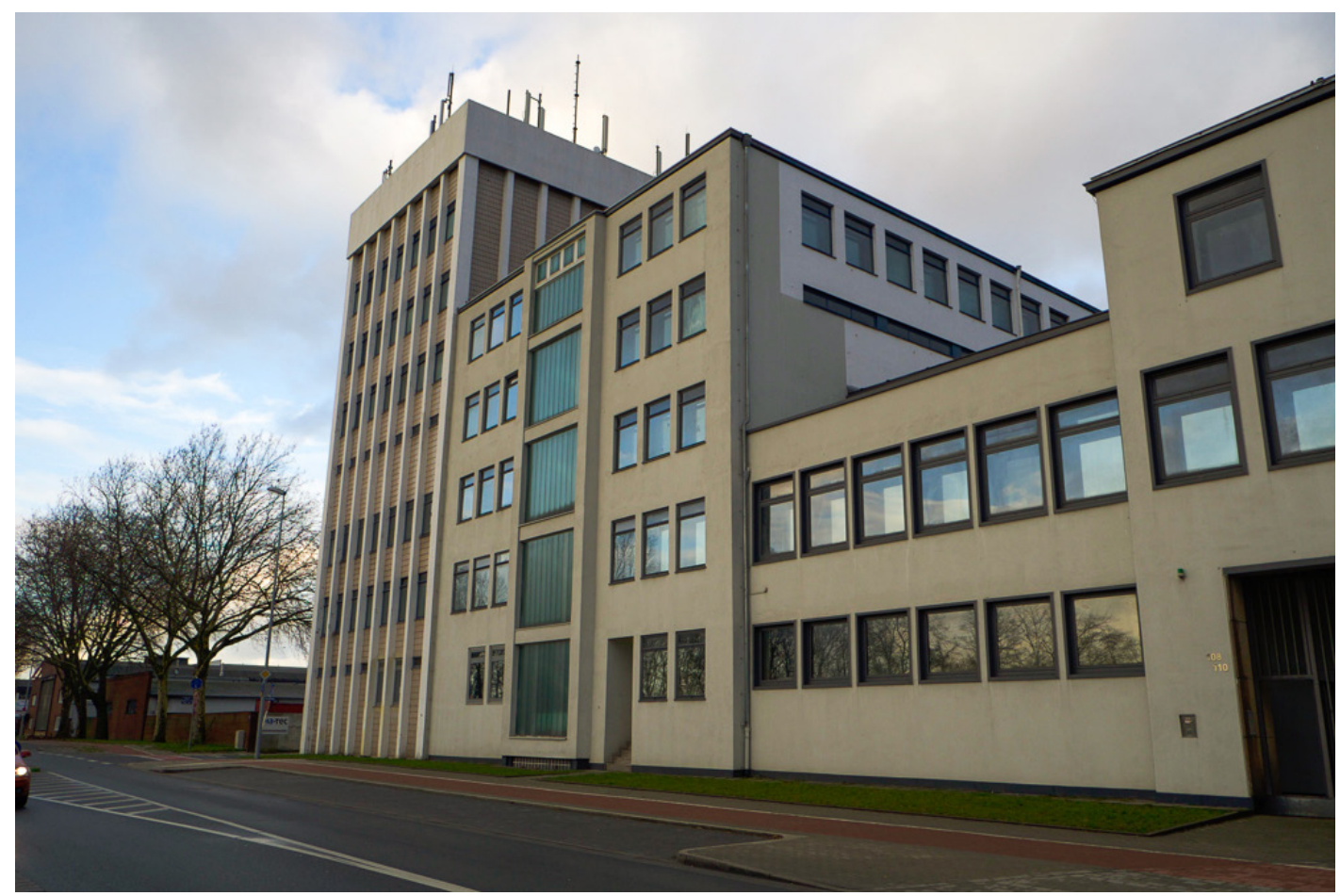

Fig. 2: The building on the Ruhrorter street; $($ J Jonas Tinius.

With help from stage designers at the Theater an der Rubr, Adem and his friends rented out and prepared two floors of the Ruhrorter building, amounting to more than a thousand square metres of dusty, abandoned, empty space. The two floors they had selected, the second and the top floor, became important sites for the project. The second floor was structured along a hallway with about thirty rooms to its right and left of equal size (about $25 \mathrm{~m}^{2}$ ). Each room had once been given to an asylum-seeking family when the building was still a refugee camp in the 1990s. Upon exploring the space with Adem, we discovered many signs of this former usage. Each door, the floor, the walls, and even the windows bore the marks of former inhabitants. Jokes, names, insults, and poems were scratched into wooden doors and scribbled onto concrete walls.

While Adem focused on rehearsals for his theatre play on the top floor of the building, one of the artists involved in the project created a participatory walk-through installation in these rooms, which they aptly named Palimpsest. The installation Palimpsest comprised multiple possible pathways to explore the institutional history, the people involved in it, and the sociopolitical background of the building - they created, in other words, "trajectories between signs" (Bourriaud 2002 [1998]: 113). Several rooms were dedicated to a newspaper archive that traced the former ownership and media coverage of the building, while other rooms had hidden loudspeakers with interviews conducted with former facility managers, therapists, and inhabitants that replayed on a loop. One room (see Fig. 2) also included excerpts from my field notes and diaries that offer insight into the rehearsal processes. This resulted from our discussions on how the "expertise and knowledge" (CEO Theater an der Ruhr) I had produced could be made visible to the audiences visiting the project. 
When the project premiered in May 2014, this installation was made accessible after each theatre performance. Audience members would walk down from the top floor, where drinks and food were served in one of the larger rooms of the installation, all the while able to explore the rooms on their own. Each person was invited to find their own way through the rooms; there was no necessary path or guidance. Actors from the project joined in for conversations that often lasted until late in the night, and the project directors made sure to invite journalists, politicians, former inhabitants, and other people that had been associated with the building and its history to facilitate an engagement with the spatial context of refugee experiences.

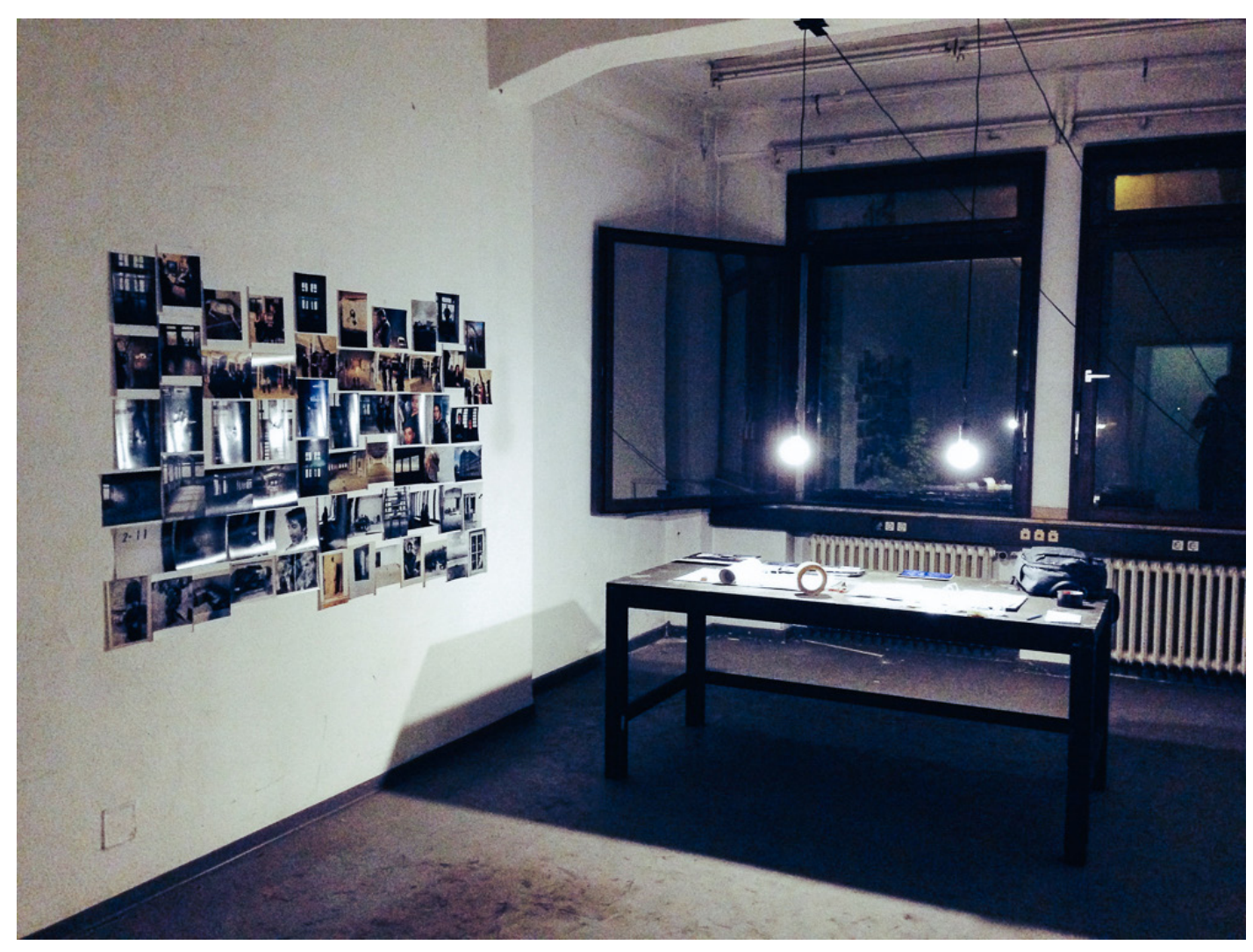

Fig. 3: One of the archive rooms in preparation; $\subset$ Jonas Tinius.

The focus of the installation resided in the social relations "implied" in the building and its "social context, rather than an independent and private space" (Bourriaud 2002 [1998]: 113). The exhibition was not merely an echo or a representation of past experiences of refugees in this building. It was, instead, an active engagement and a collective reimagination of it. Through sounds, images, and conversations - but first and foremost by way of co-presence and intersubjective encounters between audience members, former inhabitants, and current refugees - the installation facilitated a creative engagement with the project's spatial and institutional context. The Ruhrorter building became both a real historical background and a projection screen for new meanings of spatial experience as a refugee. The refugee participants of the project and the audience members became co-producers of relationships with the spatial context they temporarily populated. The artwork was thus located and emerged at the junction of different imaginations of such a space that oscillated between historical facts and present experience. In other words, the installation gave "the viewer a chance to complement" the "model of sociability" proposed by it (ibid., p. 109). It permitted the audience "to enter into dialogue" (ibid.). It is this spatial oscillation that I describe as the first plane of "dialectical fiction" facilitated by the 
Ruhrorter project and context, because it posed direct questions to viewers and participants alike. What kinds of social experiences do the space and the installation provoke? How do they disrupt existing and create new experiences with a space once marked-off for refugees?

\section{Dialectical Fiction II: Actors/characters}

One day during the first month of the project in early 2014, the Ruhrorter group (Adem, a collaborator and friend of his, as well as six refugee participants) spent a long day together in the Ruhrorter building to get to know each other better. After a walk through the golf course and horse racing track situated right next to the industrial harbour and the former asylum camp - a juxtaposition that is characteristic of the crass social contrasts of the post-industrial Ruhr valley today - we went upstairs to begin the rehearsal. Adem addressed the participants:

We have known each other for a little while already, but I would like to begin our rehearsals with an exercise that is not about us as a group or about the outside world, but about the relations you have to yourselves. I would like you all to imagine you are writing a story to someone far away, to someone who lives on an island where nobody knows who you are. Tell them your story, or a story that you have wanted to tell someone, but have so far not been able to articulate. (Fieldnotes, January 2014)

Adem hastened to add: "We are not telling each other stories that we don't want to tell. This is not an exercise in exhibiting yourself to the others. Rather, it's about getting some things off your shoulders that you've been wanting to tell. You don't even have to tell your story in German: choose your language". Marvin, the Roma participant from former Yugoslavia, remarked: "I find it good that we're in this house on the Ruhrorterstraße. It already tells us stories about us."

The participants dispersed around the room, sat down in a corner, or on the stairs leading up to the podium. Each participant began to write, some more slowly and hesitantly, others with assistance from more literate friends. One participant did not write at all and soon I noticed that he cried silently. I prodded Adem, and he immediately walked over to the young Macedonian man, telling me to come with him. The three of us sat down with another Macedonian project participant who translated our conversation. Res, as I will call him, told us that he wanted to write about how his father and uncle died on their escape from Macedonia: "I didn't know at first if I could write about it, since I thought it would take me all day. I wanted to try, but I failed - it was too intense." Adem patted him on the shoulder, saying:

Res, you have learned a very important lesson that I am trying to teach you all through rehearsals: identification is dangerous, fiction is our tool. During rehearsals, we are learning how to use this tool to be able to deal with the traumatic experiences all of you have had.

Shortly afterwards, Adem called the group together. Res and some others gathered a few chairs we had brought up to the fourth-floor makeshift stage. Adem told the group that the texts they had written - in Farsi, Turkish, French, Arabic and several other languages - were not going to be read out. "This is not the point", he said, "let me explain...":

You are all going to take your text, and imagine you are that other person you have written to. As someone else, you are now reading your letter. Imagine you are not yourself, but a fictional character in a far-away place. Don't tell me who this person is, or where you imagine this to be - that's entirely up to you. 
One participant raised his hand to get attention, shrugging his shoulders visibly to show he had not understood the exercise. In response, Marvin, the Roma boy who had been working with Adem for several years, said first to him, in Serbo-Croatian, then in German to the rest of the group: "If you imagine someone else reading your story, you can distance yourself from yourself. The question is: how do you abstract something that is so deeply personal without becoming too emotionally vulnerable - like just happened to Res." Marvin looked over to him and Res nodded. Marvin continued in German: "Once we have imagined our story as someone else's, we can then reappropriate that story as if it were not our own." Adem, the project director, listened patiently, waiting to comment in German, then in English for the Iranian and Egyptian participants:

Yes, exactly Marvin. This process of abstraction and reappropriation is at the heart of theatre, and therefore of our rehearsals. We need to introduce the fictitious into the real, otherwise we make ourselves vulnerable. This 'real', or your 'authenticity' is also how the authorities and media subdue you: they tell you that you are only your refugee self. But you are so many others. In the rehearsals we co-create a space and a praxis that help us reformulate who we are. That's when we are able to act upon ourselves as subjects. That's what I want you to learn. I am just facilitating this process, but it extends far beyond the stage.

Res was the first to get up and to try writing his story anew. The Iranian participant sat on his chair for a moment longer, pensive, before he too got up and walked through the room, eventually leaning on a column and reading his story to himself, slowly, in Farsi. Marvin, too, took his sheet of paper and, in exaggerated gestures, walked through the room, reading out the letter in Serbo-Croatian. Adem saw that I was taking notes. I told him I wrote about this process of learning to distance oneself from one's own stories. "It's interesting how you are slowly teaching them to introduce a new character into their own story", I said to him. "Yes", he responded, "and this is only the first step in a long process. You will see, this takes months, years - even some professional actors never understand this."

Half an hour later, Adem added another level of intensity to this exercise by asking everybody to come closer together. As they stood just a few feet away from each other with sheets of paper in their hands, Adem asked each participant to read out their texts, loudly and at the same time, then silently, almost inaudibly. This cacophony of different stories, he told the group later, was supposed to estrange them even further from relating to the stories as something personal, allowing for a greater distance between story and self, imagined addressee and author, character and actor.

\section{REHEARSALS AND SELF-SUBJECTION}

The scene described above constituted one of several hundred other such instances of training to reflect on the self that I witnessed during my fieldwork. Over the course of eight months, Adem introduced a plethora of different practices, methods, and exercises that involved the group and the individual actor in such methods of reflection and estrangement. These exercises were not aimed at producing a particular script for the eventual performance, but at inviting the actors to develop an attitude, a conduct, a relation to their selves and subjectivities - and in turn a form of respect for the other participants present and involved in this process. This slow training cultivated each actor's body and mind as a subject in the double sense of the term: as an active agent in creating a relationship to the self, and as a passive subject subjected to this 
reflection. The reflection, although often characterised by Adem as a relational practice that can take place with any participants, not just refugees, had a strong therapeutic dimension. In the many conversations I conducted with participants, they noted the way in which it facilitated the articulation of alternative subjective possibilities to experience stress, trauma, but also to express new ideas, aspirations, and to find self-confidence.

I use the term "dialectical fiction" to refer to the aims and means of this project, that is, its aesthetic and method. First, the project aimed to estrange viewers and participants from their usual reading of the performance venue by offering imaginary narratives of the space through fictitious memories of the refugee actors, and through encounters in the performance venue. It therefore imbricated the real historical with a fictitious locus. The space was both real location and fictitious scene. Second, not just the space, but also the bodies and characters of the actors were implied in a process of dialectical fiction. They were double in the sense that each participant rehearsed him- or herself as both real and otherwise, as imagined character and real refugee actor. It was never revealed whether the actors were playing themselves or enacting other people's experiences, refugees or non-refugees, living or dead, real or imagined people. Thus, each person on stage was implicated in a double performative gesture: both by enacting a fictitious person and by executing authentic corporeal movements that reflect on this fiction. This aesthetic form I term "dialectical fiction" was conceived by Adem and the other informants directing the project as a political critique, since it offered a corrective to realist documentary theatre; a corrective that regarded the participating refugees not as somehow "locked" in their "real" refugee character, unable to abstract from it, but as actors capable of imagining themselves as other and otherwise.

The rehearsal's aesthetic practice and its associated political critique were based on months of intense training, which, I argue, added an ethical dimension to the project. Rehearsals in the site implied months-long commitments to a particular modus and locus of theatrical practice - a process that required intense self-reflection and awareness of the institutional space and personal experiences. Since the aim of the project was to facilitate imagination, rather than curtail it through a focus on realism, each actor was constantly asked to be aware of the doublenature of their performance, too. Adem introduced what initially appeared contradictory to me, namely a strict "discipline of reflection", asking the participants again and again not to slip into "private" gestures and actions. By this he referred to the potential emotional danger of associating oneself too strongly with the characters on stage - a form known in its extreme as "method acting". ${ }^{2}$

Instead, actors trained to abstract the personal acting self from the fictitious character on stage, thus constantly engaging in a process of relating to themselves and others and reflecting on how they did so - a practice that Alex Flynn and I have analysed elsewhere as "relational reflexivity" (2015: 5). This reflection on the detachment of self from character became an ethical practice for participants, a praxis that some (more than others) took on as personal projects beyond the theatre stage. It consisted of a form of relationality that functioned through detachment and reflection - aspects of social life that are arguably overlooked in the social theory canon (see Candea et al. 2015; Strathern 1995). This dissociative and yet self-relational process of self-subjection and subjectivisation (see Foucault 1990 [1984]) constituted the telos of the

2 In method acting, actors use a set of emotional, psychological, and bodily techniques to recreate themselves in the light of the characters they enact. For a good overview, see Innes and Shevtsova (2013: 62ff). 
rehearsal: for actors to internalise the self-disciplined reflection on the dialectical fiction of their stage presence. Dialectical fiction, then, describes the initiated oscillation between "praxis (the act of self-transformation) and poiesis (the necessary, servile action aimed at producing and transforming)" (Bourriaud 2002 [1998]: 103). Since this process was not a form of individual therapy, but took place in a context of continual interaction with others, multiple relations were effectively "tightened" through the practice of dialectical fiction. Detachment, subjectivity, and relational sociality are not contradictory; they complement and enrich each other.

\section{Conclusion: double subjects AND ReLAtional REFLeXivity}

The aim of this article has been to provide an account of a participatory and site-specific art and theatre project that responds to what they perceive to be a crucial challenge for political theatre today, namely whether "it is still possible to generate relationships with the world" (Bourriaud 2002 [1998]: 9). For Bourriaud, relational aesthetics is a form of artistic practice that takes the generation of relationships between artists and spectators as both subject matter and means of art production. I hope to have complemented his claims by referring to a second kind of relationship, namely that between artists and themselves. By proposing theatrical rehearsals as a locus and modus for the production of both intra- and intersubjective reflection as well as the subjection of the self to a reflected interrogation, I hope to have indicated a productive gap in the treatment of relational aesthetics: the very question of what constitutes relationality and subjectivity.

The practice of dialectical fiction describes the recognition of the double-nature of subjectivity and relationality in theatre. This double nature refers to the introduction of fiction or a fictitious other into processes of art production that extend beyond theatre. The double, or doublement, then, is a reflexive process on relationality. But rather than introducing this reflexivity exclusively on the level of relations to others, it highlights relations of subjects to themselves. This imagination of the self as potential other, or the process of "dialectical fiction" and "relational reflexivity", I argue, defined the main trajectory and telos of the Ruhrorter refugee theatre and art installation project. As stated before, reflexivity and subsequent detachment from a single notion of identity are not individual and chaotic but collective and disciplined processes.

The "impossible political utopia" aspired to by the project director therefore characterises as much a collective telos as it describes a very personal, intrasubjective aim. Dialectical fiction is fundamentally concerned with the development of a creative autonomy through "active dissociation, alienation, self-reflexivity" (Davis 2003: 145). Many informants described detaching themselves from the stigmatising and minimal category of the refugee by introducing fiction and self-creation as a therapeutic practice. This practice and the rehearsals were by no means "democratic processes", in Bourriaud's terminology. They were shot through with self-discipline and self-subjection. However, the discipline cultivated during rehearsals aimed at greater creative autonomy of each participant and shed light on what it might mean to speak of political participatory art as "re-forming worlds of subjectivization" (Bourriaud 2002 [1998]: 104). The rehearsal process of the refugee trilogy ultimately aimed not at greater individuality or detachment from others; it emphasised the oscillation between self-reflection and engagement with others, self-care and care for others. 
By introducing this minute and ethnographic scale into the discussion of relational artistic practices and micro-utopias, I hope to have challenged and complemented Bourriaud's narrative on relational art and utopian political visions in art. His account of relational artistic practices and their political aspirations for "learning to inhabit the world in a better way" (ibid., p. 13) provides a rich vocabulary for analysing performative practices in and beyond the art world - but it equally requires more nuanced accounts of what, who, and how we relate in art to form and reform subjectivity of such learning processes. If relational aesthetics - and by my extension, participatory political theatre with refugees at the Theater an der Rubr - is about the creation of relations and the formation of a reflexive subjectivity, then ultimately it is also about the cultivation of the subjects enacting and severing these relations.

\section{References Cited}

Agamben, Giorgio. 1998 [1995]. Homo Sacer. Sovereign Power and Bare Life. Stanford, CA: Stanford University Press.

Alloa, Emmanuel. 2015. Penser l'image II. Anthropologies du visual. Paris: presses du réel.

Artaud, Antonin. 1958 [1938]. Theatre and its Double. Translated by Mary Caroline Richards. New York: Grove Press.

Barnett, David. 2015. Brecht in Practice. Theatre, Theory and Performance. London: Bloomsbury. Bishop, Claire. 2004. "Antagonism and Relational Aesthetics." October 110 (Fall): 51-79.

- 2012. Artificial Hells: Participatory Art and the Politics of Spectatorship. London/New York: Verso.

Bourriaud, Nicolas. 2002 [1998]. Relational Aesthetics. Translated by Simon Pleasance and Fronza Woods. Paris: les presses du réel.

Boyer, Dominic. 2005. Spirit and system: Media, Intellectuals, and the Dialectic in Modern German Culture. Chicago: University of Chicago Press.

Brecht, Bertolt. 2014 [1948]. "Short Organon for the Theatre." Pp. 229-255 in Brecht on Theatre, edited by Marc Silberman, Steve Giles, and Tom Kohn. $3^{\text {rd }}$ Edition. London: Bloomsbury.

Bürger, Peter. 1984 [1974]. Theory of the Avant-Garde. Minneapolis: University of Minnesota Press.

Candea, Matei, Joanna Cook, Catherine Trundle, and Thomas Yarrow. Eds. 2015. Detachment: Essays on the limits of relational thinking. Manchester: Manchester University Press.

Cook, Bill and Uma Kothari. 2001. Participation. The New Tyranny? London/New York: Zed Books.

Davis, Tracy C. 2003. “Theatricality and Civil Society.” Pp. 127-155 in Theatricality, edited by Tracy C. Davis and Thomas Postlewait. Cambridge: Cambridge University Press.

Flynn, Alex and Jonas Tinius. 2015. "Reflecting on political performance: Introducing critical perspectives." Pp. 1-28 in Anthropology, Theatre, and Development: The Transformative Potential of Performance, edited by Alex Flynn and Jonas Tinius. Basingstoke: Palgrave Macmillan.

Foster, Hal. 1996. "The Artist as Ethnographer" in The Return of the Real. Cambridge, Mass.: MIT Press.

Foucault, Michel. 1990 [1984]. The History of Sexuality. The Use of Pleasure. Vol. II. New York: Vintage Books (Random House).

Innes, Christopher and Maria Shevtsova. 2013. The Cambridge Introduction to Theatre Directing. Cambridge: Cambridge University Press. 
Iser, Wolfgang. 1993 [1991]. The Fictive and the Imaginary: Charting Literary Anthropology. Baltimore: Johns Hopkins University Press.

Long, Nick. 2015. "For a verbatim ethnography." Pp. 305-333 in Anthropology, Theatre, and Development. The Transformative Potential of Performance, edited by Alex Flynn and Jonas Tinius. Basingstoke/New York: Palgrave Macmillan.

Nield, Sophie. 2014. “'Speeches that draw tears': Theatricality, commemoration and social history." Social History. 39 (4): 547-556.

Nikitin, Boris, Carena Schlewitt and Tobias Brenk. Eds.2014. Dokument, Fälschung, Wirklichkeit. Materialband zum zeitgenössischen Dokumentartheater. Bielefeld: transcript.

Pine II, B. Joseph and James J. Gilmore. 1999. The Experience Economy: Work is Theatre and Every Business a Stage. Boston: Harvard Business School Press.

Plessner, Helmuth. 1982 [1948]. "Zur Anthropologie des Schauspielers.” Pp. 146-163 in: Mit Anderen Augen: Aspekte einer Philosophischen Anthropologie. Berlin: Suhrkamp.

Sansi, Roger. 2015. Art, Anthropology and the Gift. London: Bloomsbury.

Schmidt, Theron. 2010. "'We say sorry': Apology, the Law and Theatricality.” Law Text Culture. 14 (1): 55-78.

Severi, Carlo. 2003. "Warburg anthropologue ou le déchiffrement d'une utopie. De la biologie des images à l'anthropologie de la mémoire." L'homme. 165: 77-128.

Stegemann, Bernd. 2015. Lob des Realismus. Berlin: Theater der Zeit.

Strathern, Marilyn. 1995. The Relation: Issues in Complexity and Scale. Cambridge: Prickly Pear.

- 1996. 'Cutting the Network'. Journal of the Royal Anthropological Institute 2 (3): 517-535.

Tinius, Jonas. 2015a. "Aesthetics, Ethics, and Engagement: Self-Cultivation as the Politics of Engaged Theatre." Pp.171-202 in: Anthropology, Theatre, and Development: The Transformative Potential of Performance, edited by Alex Flynn and Jonas Tinius.Basingstoke/ New York: Palgrave Macmillan.

— . 2015b. "Der Theaterberater." Interview by Elena Philipp. Tanzraumberlin-Magazin. November/December 2015: 14-15.

Venkatesan, Soumhya. 2012. 'The task of anthropology is to invent relations: The 2010 meeting of the Group for Debates in Anthropological Theory' (Special Issue). Critique of Anthropology 32 (1): 43-86.

Date received: 2015-05-31

Date accepted: 2015-10-04 